\title{
Olive cultivation in the era of globalization
}

\author{
J.D. Sánchez-Martínez, A. Garrido-Almonacid
}

\begin{abstract}
The consumption of olives and olive oil is very established in the Mediterranean. Also, the great gastronomic and health consideration of these products, as well as their relative scarcity and specificity makes them well considered and paid in the globalised markets, which have absorbed without difficulty the increase in production experienced in the last decades. In this context we witnessed the expansion and intensification of its production in its region of origin, but it is also being planted in areas which do not necessarily share the ideal thermopluviometric conditions for this crop. The purpose of this paper is to show, in a spatiotemporal point of view, the expansive dynamic of the olive tree. The main conclusion is this cycle has a very important potential growth ahead, but is not exempt of limitations and doubts, both for the new productive regions and the Mediterranean regions that are specialised in this millennial crop.
\end{abstract}

Keywords—olive oil; table olives; agrobusiness; monoculture; economic globalisation

\section{INTRODUCTION}

The production and consumption of olive oil are deeply rooted in the Mediterranean, although it represents only a tiny share of the vegetable fats sold in the world, below $2 \%$ on average in the five-year period 2010-2015. In addition, the trend is towards a progressive reduction of its participation in this world basket, and not because it is not experiencing increased growth-global production of olive oil quadrupled between 1961 and 2016 - but rather because of the much greater increases in the vegetables oils obtained from palm, soya, rapeseed and sunflower, by far the most dominant oleaginous plants, as shown in Table 1.

Table 1

Evolution of the global production of the principal vegetable fats in the world (in millions of tonnes) and the importance of olive oil between 2010-2011 and 2014-2015

\begin{tabular}{lrrrrrr}
\hline Item & $\mathbf{2 0 1 0 - 2 0 1 1}$ & $\mathbf{2 0 1 1 - 2 0 1 2}$ & $\mathbf{2 0 1 2 - 2 0 1 3}$ & $\mathbf{2 0 1 3 - 2 0 1 4}$ & $\mathbf{2 0 1 4 - 2 0 1 5}$ & Average \\
\hline Palm & 49.14 & 52.44 & 56.49 & 59.42 & 62.44 & 55.99 \\
\hline Soybean & 41.40 & 42.73 & 43.10 & 44.96 & 47.37 & 43.91 \\
Rapeseed & 23.03 & 24.10 & 24.92 & 26.43 & 26.98 & 25.09 \\
Sunflower seed & 12.21 & 14.73 & 13.27 & 15.75 & 15.16 & 14.22 \\
Palm Kernel & 5.75 & 6.16 & 6.57 & 6.99 & 7.29 & 6.55 \\
Peanut & 5.31 & 5.29 & 5.49 & 5.58 & 5.52 & 5.44 \\
Cottonseed & 4.96 & 5.22 & 5.21 & 5.13 & 5.13 & 5.13 \\
Coconut & 3.71 & 3.41 & 3.66 & 3.46 & 3.43 & 3.53 \\
Olive oil & $\mathbf{3 . 2 7}$ & $\mathbf{3 . 4 5}$ & $\mathbf{2 . 4 4}$ & $\mathbf{3 . 1 5}$ & $\mathbf{2 . 3 4}$ & $\mathbf{2 . 9 3}$ \\
Total & 148.76 & 157.53 & 161.13 & 170.87 & 175.65 & 162.79 \\
\% Olive & $\mathbf{2 . 2 0}$ & $\mathbf{2 . 1 9}$ & $\mathbf{1 . 5 1}$ & $\mathbf{1 . 8 4}$ & $\mathbf{1 . 3 3}$ & $\mathbf{1 . 8 0}$ \\
\hline & & & Source: United States Department of Agriculture, 2016.
\end{tabular}

Received: 11/12/2017, Accepted: 27/01/2018; Published: 30/3/2018

J.D. Sánchez-Martínez, Departamento de Antropología, Geografía e Historia, Universidad de Jaén, Spain

E-mail: jdsanche@ujaen.es

A. Garrido-Almonacid, Departamento de Ingenería Cartográfica, Universidad de Jaén, Spain

E-mail: agarrido@ujaen.es
Being a food with much higher prices than those of its direct competitors (Figure 1), the demand for olive oil owes much to the gastronomic appreciation and the recognition of its beneficial health effects as a fundamental component of the Mediterranean diet (Barjol, 
2014; Rastoin, 2016). These aspects have opened up new and broader perspectives, just as they have for the consumption of olives. In the context of globalization, for the traditional producer territories it is a great economic opportunity that has been translated into a strengthening of regional specialization, as has occurred paradigmatically in the south of Spain (Sánchez and Paniza, 2015). But there are also cases of new producing territories all over the world, even in areas where climate conditions differ markedly from those typical of their place of prime acclimatization, but in which they try to reproduce the productivist models that have been honed in countries such as Italy or Spain. The fact is that the olive acreage has tripled in the last fifty years, being present today in fifty-six countries. Far from being stabilized, a multitude of expansion plans in old and new producing countries suggest an expansive trend for the coming decades. In the present work we intend to examine the reasons that explain these processes of expansion, putting special emphasis on some of the most outstanding cases. Likewise, we will try to explain the fundamental role that Spain is playing in their development, in terms of both the production and export of products and the generation of knowledge, training, capital and technologies that are being applied all over the world.

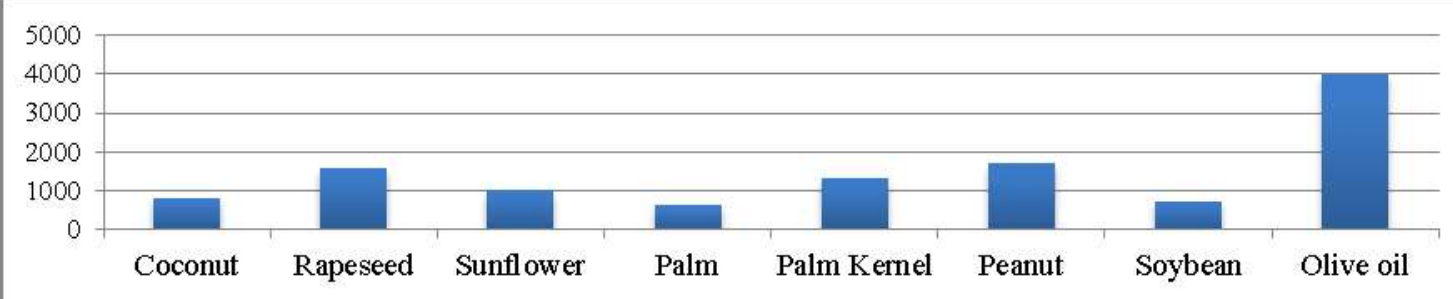

Figure 1. Comparison of the international price of vegetable fats (US \$/tonne in June 2016) Source: http://www.indexmundi.com/commodities/ (Last accessed on 20 January 2017)

\section{CONCEPTUAL FRAMEWORK}

Without reaching the economic, environmental and social magnitudes and repercussions of soybean or oil palm crops (Pérez-Carrera, Moscuza \& Fernández Cirelli, 2008; Jiménez, 2008 ), to cite only two examples that are also related to the production of soybean and palm oil, the production of vegetable fats in the Mediterranean area has also been moving towards the consolidation of monocultures, with olive groves and vineyards standing out from the rest. The ultimate cause of agricultural monocultures, as they present themselves nowadays, is neoliberal-inspired economic globalization, which has overthrown numerous tariff and trade barriers (Clare, 2014) and has enabled the emergence of the so-called "third food regime" (Bernstein, 2015).

Throughout the world one can find paradigmatic cases of the speed and depth of changes associated with extreme regional specialization. Accordingly, in the face of achievements related to the adoption of canonical productivist principles, there have also been perverse effects such as land grabbing, massive displacements towards the suburbs of the large growing cities of less developed countries, or severe losses of biodiversity. In all these cases, the almost universal tendency to concentrate agrarian and agroindustrial activity in large corporations, specialized in earning profits through economies of scale (McMichael, 2014) has also been observed. Of course, the regional specialization of agriculture is a very old issue. Throughout the eighteenth and nineteenth centuries, monocultures already reached very significant dimensions in the new countries that had previously been colonized by European metropolis, both in tropical areas and in temperate climates. One of the most studied cases is that of the large slave plantations of sugarcane in the countless "sugar islands" of the Caribbean (Stinchcombe, 1996). Similarly, market unity, accelerated industrialization, and the development of a highly efficient communications system facilitated the creation of the great homogeneous production belts of the United States during the twentieth century (Moore, 2003). 
The modern monocultures to which we are referring reach ever greater sizes and employ strategies that fully participate, as has been pointed out, in the principles of agricultural productivism, that is, that are accompanied by formulas to significantly increase the crops and that are associated with corporate concentration (Moreno-Pérez, 2013). Given that the possibility of relocation of agricultural production exists, certain territories and crops in Western Europe have tried to move towards postproductivist models (Wilson 2001, OECD 2006), as they may not be able to withstand the competition from these new producers. Of course, this is more complicated in the case of crops that are linked to limited climatic ranges, as evidently occurs with the olive tree.

The olive tree (Olea europaea) is the only plant of agricultural interest of its kind, belonging to a family that is made up of about 600 species. Its habitat is a latitudinal strip between the 30th and 45th parallels of both hemispheres, in regions characterized by hot, dry summers, moderate precipitation and seasonal contrast, with some accumulation of cold during the winter. However, in recent years it has also been penetrating tropical latitudes in areas of a certain altitude or continentality, in this way trying to compensate for crossing the usual latitudinal boundary (Civantos, 2004).

The earliest evidence of the plant's domestication has been located north of the Dead Sea in deposits whose antiquity is dated to about 4,000 years. Vegetative propagation by cloning permitted its rapid geographic expansion and varietal diversification, accelerating the selection process in search of its best economic uses throughout the Mediterranean. In this way, it became adapted to highly contrasted regional and local environmental conditions (Rallo Romero et al., 2005). In its journey through the Mediterranean lands and civilizations of antiquity, it reached its western extremity, the Iberian Peninsula, with the Phoenicians, although its peak coincided with the end of the Punic Wars (146 BC) when Baetica, the most southern province of Hispania, specialized in its cultivation to supply Rome. Like many other plant and animal species, it was also in Andalusia where the genetic material was collected that reached the American territories conquered by the Hispanic Monarchy from the 16th century, becoming acclimatized in regions comparable to that of its place of origin, in territories of the current republics of Mexico, Peru, Chile and Argentina in the second half of that century. A few decades later it was introduced in California and southern Brazil, and it was not until the 19th century that it arrived in Australia and New Zealand (El-Kholy, 2012). Much more recent is the expansion in other areas of the planet, such as China, Japan or Uruguay, not to mention cases more exotic but very limited in surface area such as Ethiopia, India, Angola, Mozambique, Namibia, South Africa or Botswana (Vilar \& Cárdenas, 2016). These examples mean, however, that olive groves have ceased to be exclusively Mediterranean (see Map 1) and suggest that the process of expansion around the world is far from complete

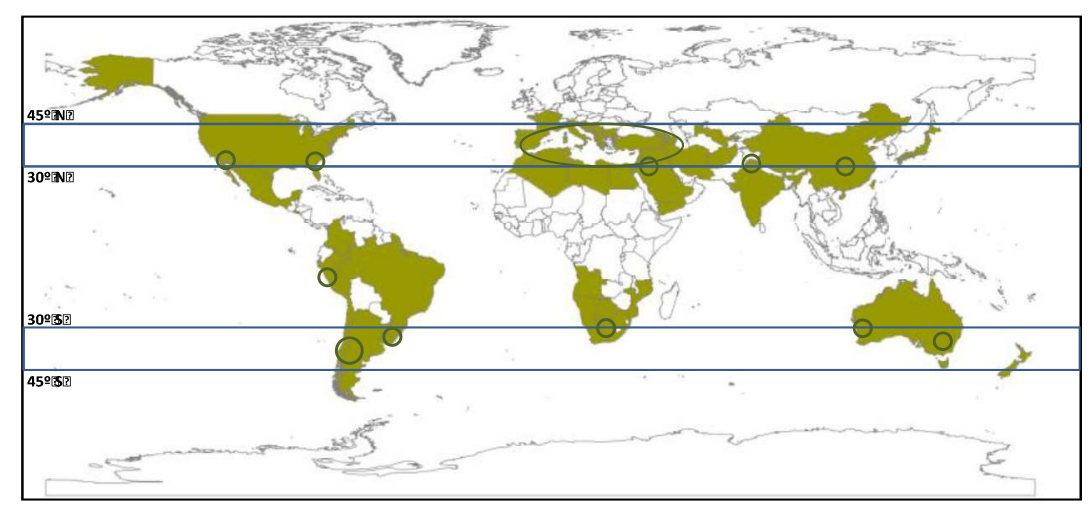

Map 1. Countries and main regions in which the cultivation of olive trees occurs (2016) 


\section{MATERIAL AND METHODS}

Along with a review of specific literature, the search for technical reports generated by different national agencies where expansions of the crop are being produced, the systematic use of news in the general and specialized press and the treatment of statistical information provided by national and international organizations, this research has also been enriched by a dozen in-depth interviews with experts based in Spain. They are, in all cases, prominent leaders in their different fields of expertise (political, business, technical and academic) with recognized international visibility, which provides them with first-hand knowledge of the processes of change that are discussed in this article. The interviews have been carried out over the last three years, forming part of a broader documentation process that covers other aspects related to the territorial dynamics of the areas of olive specialization, especially the region of Andalusia and, in particular, the province of Jaén, the most extreme case of monoculture in the world (Sánchez \& Paniza, 2015, Rodríguez, Sánchez \& Gallego, 2017).

\section{RESULTS}

The surface area dedicated to olive cultivation has increased fourfold since the United Nations Food and Agriculture Organization (FAO) began collecting reliable statistical information on this subject (1961). Table 2 shows the detail of the area under production together with the behaviour of each continental grouping. At that level, European leadership is recognized as well as the precocity within the generalized expansive process, partly as a consequence of the significant support received through the Common Agricultural Policy (CAP). Thus, for more than three decades (EEC, 1966; EU, 1999) Italy and France, first, then Greece, Portugal and Spain from the time of their accession to the European Economic Community (now the European Union) in the 1980s, have benefited from different types of aid linked to production and an intervention mechanism that was effective in preventing prices from falling below the level that ensured profitability for producers (Rodríguez, Sánchez \& Gallego, 2017).

Table 2. Evolution of the continental distribution of harvested area of olive groves (ha)

\begin{tabular}{|c|c|c|c|c|c|c|}
\hline \multirow[t]{2}{*}{ Area } & \multicolumn{2}{|c|}{1961} & \multicolumn{2}{|c|}{1991} & \multicolumn{2}{|c|}{2014} \\
\hline & Area & $\%$ & Area & $\%$ & Area & $\%$ \\
\hline Europe & $1,292,170$ & 49.53 & $4.311,671$ & 58.00 & $5,047,057$ & 49.13 \\
\hline Africa & 697,800 & 26.75 & $1,995,220$ & 26.84 & $3,287,140$ & 32.00 \\
\hline Asia & 598,436 & 22.94 & $1,058,219$ & 14.24 & $1,783,556$ & 17.36 \\
\hline America & 19,310 & 0.74 & 68,308 & 0.92 & 125,105 & 1.22 \\
\hline Oceania & 1,088 & 0.04 & 400 & 0.01 & 29,690 & 0.29 \\
\hline Total & $2,608,804$ & 100.00 & $7,433,818$ & 100.00 & $10,272,547$ & 100.00 \\
\hline
\end{tabular}

Source: http://www.fao.org/faostat/es/\#data/QC

Since the last decade of the twentieth century, however, the most significant relative growth has occurred on other continents. In this table, as indicated, the official statistic only includes the area harvested and, in addition, by observing the detail by country, we can see the absence of the most recent producers, either due to defects in the collection of information from their respective statistical services, or because the productions are so insignificant that they do not appear. It is, therefore, not inaccurate to say that the global surface area of olive groves had exceeded 11 million hectares in 2015. In fact, the year before, an estimated 75,000 new hectares were planted, especially in countries such as Morocco, Tunisia,
Portugal, Chile, Saudi Arabia, China and India. ${ }^{1}$

Some of these countries have plans in place to continue to significantly increase the area devoted to cultivation, and more than a few have also expressed their intention to do so on a more modest scale due to their geographical characteristics.

These figures make the olive grove one of the permanent crops with the largest area occupied on the planet, above the total for bananas and plantains (9.9 Mha), but clearly exceeded by citrus (14.5 Mha) and palm oil (18.7 Mha), all of which are absent or minimally represented on the

\footnotetext{
${ }^{1}$ Information from ABC newspaper, October 5, 2015 http://sevilla.abc.es/andalucia/jaen/20151005/sevi-cultivoolivar-hace-global-201510051725.html
} 
European continent. Observing the magnitudes corresponding to the average volumes of oil and olive production in recent years (Tables 3 and 4), it is clear that countries with a strong olive tradition continue to lead in a very prominent way. In essence, it remains a crop of the Mediterranean basin and very much dominated by Spain, which occupies first place in a very conspicuous way. The major part of the consumption and export also belong to this group of countries. However, the proportion of both aspects has slightly declined in recent decades, as a logical consequence of the expansion of markets and the emergence of new producers. At the moment, this latter set of countries obtains harvests that do not come close to challenging the global leadership, with Argentina being the only case highlighted.

Table 3. The top four producers of olive oil according to their location Average figures for the period 2011-2015 (in thousands of tonnes)

\begin{tabular}{|l|r|l|r|r|r|}
\hline \multicolumn{2}{|c|}{$\begin{array}{c}\text { Mediterranean countries } \\
\text { of the European Union }\end{array}$} & \multicolumn{2}{c|}{$\begin{array}{c}\text { Mediterranean countries } \\
\text { of Africa and Asia }\end{array}$} & \multicolumn{2}{c|}{$\begin{array}{c}\text { Other countries from } \\
\text { the rest of the world }\end{array}$} \\
\hline Spain & $1,275.1$ & Turkey & 164.0 & Argentina & 61.6 \\
\hline Italy & 402.5 & Tunisia & 178.0 & Australia & 16.0 \\
\hline Greece & 284.3 & Morocco & 121.7 & Chile & 17.1 \\
\hline Portugal & 76.7 & Syria & 158.0 & China & 3.8 \\
\hline Total & $2,038.6$ & Total & 621.7 & Total & 98.5 \\
\hline \multicolumn{4}{|c|}{ Source: International Olive Oil Council (last accessed 31-12-2016) }
\end{tabular}

http://www.internationaloliveoil.org/estaticos/view/130-survey-and-assessment-division

Table 4. The top four producers of table olives according to their location Average figures for the period 2011-2015 (in thousands of tonnes)

\begin{tabular}{|l|r|l|r|r|r|}
\hline \multicolumn{2}{|c|}{$\begin{array}{c}\text { Mediterranean countries } \\
\text { of the European Union }\end{array}$} & \multicolumn{2}{c|}{$\begin{array}{c}\text { Mediterranean countries } \\
\text { of Africa and Asia }\end{array}$} & \multicolumn{2}{c|}{$\begin{array}{c}\text { Other countries from } \\
\text { the rest of the world }\end{array}$} \\
\hline Spain & 558.5 & Egypt & 418.0 & Argentina & 197.9 \\
\hline Greece & 167.9 & Turkey & 392.8 & USA & 71.3 \\
\hline Italy & 66.5 & Syria & 133.0 & Peru & 68.9 \\
\hline Portugal & 14.6 & Morocco & 108.3 & Chile & 25.6 \\
\hline Total & 807.5 & Total & $1,052.1$ & Total & 363.7 \\
\hline
\end{tabular}
http://www.internationaloliveoil.org/estaticos/view/130-survey-and-assessment-division facts help us to appreciate, if anything, the truly

With regard to consumer countries outside the Mediterranean world, there are some demographic giants with a significant ethnic Latino component, such as the USA or Brazil, some other countries where this element is less prominent (Australia), or absent (Japan), and countries that are still part of the European Common Market, such as Germany, the United Kingdom and France. These global status that this crop has acquired and the products that are obtained from it. We can consider this global framework, therefore, as being appropriate for understanding its recent and future dynamics. Figure 2 shows the significant increase in olive-based products in the last quarter century. 


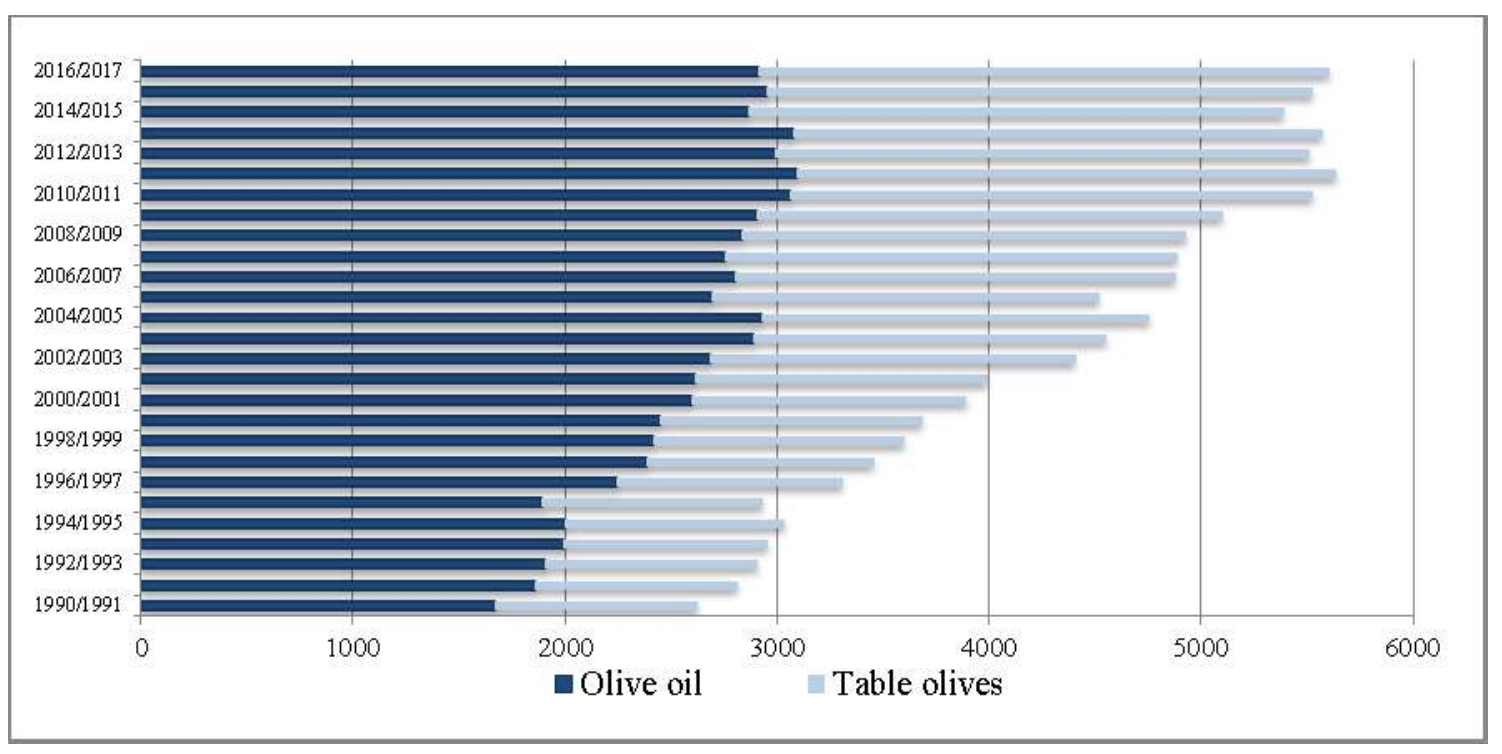

Figure 2. Evolution of the global consumption of olives and olive oil (in thousands of tonnes) since 1990 (*) (*) The data for the 2015/2016 campaign are provisional and 2016/2017 a forecast.

Source: International Olive Council (Last accessed on 02-01-017). http://www.internationaloliveoil.org/estaticos/view/130-survey-and-assessment-division

The role of Spain has been key in this process of expansion in the production and the consumption of oil and olives. Let us now turn to a subject that is especially important to this case: the development of methods for the intensification of production. From the outset, the productive stimulus that Spain received when it acceded to the European Union not only translated into an increase in the cultivated area, but it signified, principally, a decisive wager on mechanization, the systematic use of inputs and the gradual adoption of irrigation, something quite novel if one considers that the olive tree was always considered a rain-fed crop. The results of this process can be seen in Figure 3, in which it is clear that despite all the improvements in farming techniques, the size of the olive harvest varies greatly and is sensitive in any case to the meteorological conditions of each season in the context of the wide variability that characterizes the Mediterranean climate. On the other hand, far from generating absolute advantages, the intensification of production is paid for with significant environmental and socioeconomic returns (Delgado, 2012). The worldwide spread of olive oil as a fundamental component of the Mediterranean diet is, for the moment, subject to the generation of an important ecological footprint in the extreme monoculture zones, which is a contradiction (Scheidel and Krausmann, 2011).

Since the beginning of the 21st century, partly as a result of the environmentally unsustainable habits of the green revolution promoted under the CAP, aid in the European Union has been steered from price and market policies towards rural development. Ironically, this circumstance has increased the interest of technicians, researchers and investors in developing new and even more productivist formulas. In fact, one characteristic shared by the current expansion of the olive tree around the world is the adoption of intensive and super-intensive plantings. As we have said, the development of these agronomic methods that permit greater harvests, reduce costs and even increase the quality of the product, have been developed, in part, in EU countries as a formula to compete in a context of strict market conditions, that is, in which no aid other than rural development could be accepted. 


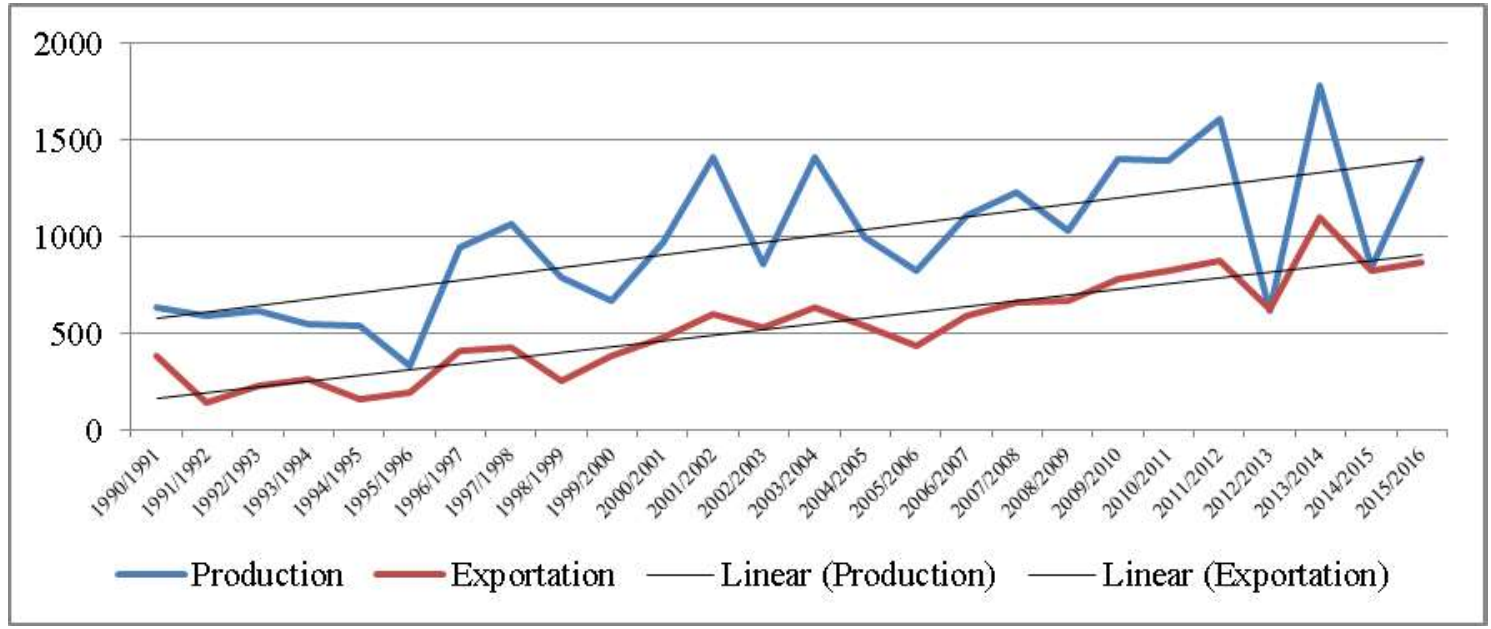

Figure 3. Absolute evolution (thousands of tonnes) and trend line of the production and export of Spanish olive oil (1990-2016)

Sources: International Olive Oil Council and Olive Oil Agency http://www.internationaloliveoil.org/estaticos/view/131-world-olive-oil-figures?lang=es ES https://servicio.magrama.gob.es/InformacionMercado Aica/InfMercadosAceite.aao? Aplic=IMA\&OpcMenu=EXPME\&dato $\underline{\text { de }=\text { EXPORTACION }}$

These same systems have been well received in the new projects developed all over the world. In this way, the prototype of modern exploitation is the one that has a surface area large enough to justify complete mechanization and even the implementation of its own milling systems and direct sales with its own brand. The speed with which the most advanced machines perform the harvest, the choice of the most appropriate moments to proceed with the harvesting of the fruit, and the great industrial capacity of the oil mills are elements that allow us to understand the productive strategy as a compromise between quantity and quality. This is demonstrated by the fact that, from the outset, direct marketing is targeted at the most demanding markets and those that pay the most for the product. This is a big difference from the traditional territories, where productive small farms and the existence of processing cooperatives that operate as bulk sellers in the intra-industry market are frequent, which is one of the most distinctive features of the Spanish case (USDA, 2013).

In Spain, in addition to the exceptional case of the province of Jaén, which has reached a situation of almost total monoculture, the most recent expansions have taken place in the province of Seville, where the soil conditions, property structure and availability of water have lead to the recovery of a crop that was present at other times, but was uprooted in the second half of the twentieth century due to a lack of profitability, and that is returning today under the productivist approaches described above.

In Europe, however, the most recent and spectacular case of olive grove expansion is that of the Portuguese Alentejo (Sánchez \& Gallego, 2012). This region contains $48.35 \%$ of the country's olive-growing area $(169,896$ ha) and produced $74.03 \%$ of the oil obtained in Portugal in 2013. ${ }^{2}$ This is one of the clearest examples of the influence that the investment, technology, knowledge and the training capacity amassed in the south of Spain has had in this latest wave of the spread of modern olive growing techniques throughout the world. In fact, at the time there was talk of a 'landing of Spaniards' in this region of Portugal and their important role is recognized in the revolution in production experienced in this area, which has allowed Portugal to surpass for the first time in its history a production of 100,000 tonnes of oil in the last campaign. ${ }^{3}$ Of course, the olive agro-business that has arisen here contrasts

${ }^{2}$ Surface area of major agricultural crops; Olive oil produced by geographical location. Retrieved from Statistics Portugal:

https://www.ine.pt/xportal/xmain?xpid=INE\&xpgid=ine base dados

${ }^{3}$ https://revistaalmazara.com/2016/07/18/los-olivaressuperintensivos-del-alentejo-permiten-a-portugal-alcanzar-las$\underline{100-000-\text { toneladas-anuales/ }}$ 
notably with the model of family agriculture dominant in this country. Among the reasons that have permitted the development of the new olivegrowing landscapes in Alentejo are the availability of abundant, safe and inexpensive water provided by the Alqueva dam $\left(4,150 \mathrm{Hm}^{3}\right)$ or the possibility of acquiring land with good agronomic conditions at prices that were initially extraordinarily attractive. The first Spaniards to invest were paying in the range of $€ 3,000 / \mathrm{ha}$, when the average price of olive groves in Spain was $€ 25,000 / \mathrm{ha}$, but three times this figure for the best irrigated farms, which augured a safe capitalization when planting, especially when one takes into account that the installation of the infrastructure for irrigation and the processing industry were able to benefit from the generous support received under the Rural Development Plan then in force. To all this was added the lower remuneration of the agricultural workers, the physical and idiomatic proximity and the legal security granted by the fact that both countries belong to the European Union.

Another paradigmatic case is that of Morocco. With 580,000 hectares planted in 2003, the goal was set to reach one million ha by 2015 , a goal they have basically achieved. The new olive groves have modified the production landscape, but also the preferred destination of the fruit, which until then had been dominated by the olive for direct consumption, and which is now more focused on the production of oil. As in the other cases, this has also involved a radical change in the type of varieties used. In the Mediterranean basin hundreds of different biotypes are found that come from the acclimatization to local conditions. In the new plantations, however, those that best meet the standardized requirements of international markets are sought. The Arbequina, Arbosana and Picual varieties, coming from Spain, or Kororiki and Frantoio, from Greece and Italy respectively, are some of the most used. What is more, along with the plantations created in the most favourable areas of the country, an export plan has also been conceived. This is reflected in both the Plan National Oléicole (1988-2010) and the Plan Maroc Vert (Agence por le Développement Agricole, 2009), supported by the European Union and that also encourages foreign investment. At the moment, it has been reported that in the last six years the production of olive oil in this country has doubled ${ }^{4}$ and it has been announced that the new horizon is 1.2 million ha by $2020 .{ }^{5}$ The Moroccan plans are an example that has been repeated in Tunisia ${ }^{6}$ or Algeria $^{7}$. In South America, Uruguay (Parras, 2013) and Brazil (in the state of Rio Grande do Sul) are also taking the first steps to quickly create specialized regions. In both cases there is intense demand for technical and instructional advice from the olive orchard district of Jaén (Rodríguez and Parras, 2011).

In North America, regional specialization is also being strengthened in California ${ }^{8}$, which is expected to increase by 1,400 ha annually until 2020 , but it is more surprising to see a new production area in the south-eastern United States, which encompasses a strip of potential expansion across northern Florida and the south of South Carolina, Georgia (where plantations are already in operation), Alabama and Mississippi, at latitudes similar to those that in Texas also allow quality oils to be obtained. The study of the agronomic and climatic conditions for the development of this new zone was prepared by an Australian company that is familiar with the process of expansion of the superintensive models in its country, which are the ones desired to be reproduced here (Paul Miller \& Associates, 2012).

In China, studies have been carried out to evaluate the ecological possibilities of growing olive trees in certain higher altitude subtropical areas (Guo, Yan, Fan, Wanze, \& Li, 2010). There is newly arrived information that clarifies the intention of the Chinese government to plant 59 million olive trees in the valley of the Bailong River, a quantity equivalent to the total number of

${ }^{4}$ Olimerca, newspaper specialized in news from the olive sector, September 5, 2016

http://www.olimerca.com/noticiadet/la-produccion-deaceite-de-oliva-en-marruecos-se-duplica-en-seisanos/246db43596a399b4167de631edc2da6d

${ }^{5}$ Olimerca, newspaper specialized in news from the olive sector, December 23, 2016

http://www.olimerca.com/noticiadet/horizonte-2020-enmarruecos-llegar-a-12-mm-de-hectareas-deolivar/85a7f935971c5ea1613e14889fde0e16

${ }^{6}$ Olimerca, November 10, 2015

http://www.olimerca.com/noticiadet/tunez-plantara-5millones-de-olivos/434fbb0d976695289dcd7a2526065997

${ }^{7}$ New appearing in El País, November 8, 2016 http://economia.elpais.com/economia/2016/11/05/actualida $\underline{\mathrm{d} / 1478370094 \text { 799794.html }}$

${ }^{8}$ Information from Olimerca, January 3, 2017

http://www.olimerca.com/noticiadet/california-aumentarasu-olivar-en-1400-haano-hasta-el2020/4297ced88737c8994b81f7b0b46989dd 
olive trees existing in Jaén, although occupying a much smaller area because they would be superintensive plantations, within a plan to reach 86,000 ha, of which 23,000 are already in production ${ }^{9}$.

\section{DISCUSSION AND CONCLUSIONS}

The global production and consumption of olive products has increased without becoming unbalanced. In the case of olive oil, global consumption has doubled and for table olives, it has tripled (Figure 3). It is symptomatic, in this regard, that although the European Union is the world's largest producer, it has never encountered the problems of surpluses that have overwhelmed other sectors (beef, butter, milk), despite the generous subsidies that have stimulated production for decades. The immediate prospects seem to indicate that the expansive process will continue. Among the reasons that allow us to make this affirmation, there is the demographic increase and, in particular, that of the middle classes with greater purchasing power, both in the areas of traditional consumption of the Mediterranean countries and outside this zone. In this regard, the aspects related to health and nutrition are the most important asset in olive oil, a fat that contains a high percentage of monounsaturated fatty acids and does not bear the serious environmental and social controversies that affect palm or soya oils. At the moment, per capita consumption in countries such as the USA, Brazil, Germany, China, the UK or Germany is extremely low and, therefore, there is huge potential for a significant upward trend.

In all the countries where the habit of consuming oil and olives has been introduced and where they believe that they have appropriate ecological conditions, attempts are made to develop plantations to serve the local markets, as we have seen in the case of Brazil, China or the USA. These plans to replace imports are complemented by export specialization in countries where consumption has not yet taken root or where the absorption capacity of the products by the domestic market is very small compared to the production capacity, as is the case in Argentina, Chile and Portugal. Although the

${ }^{9} \mathrm{http}: / /$ www.olimerca.com/noticiadet/california-aumentarasu-olivar-en-1400-haano-hasta-el2020/4297ced88737c8994b81f7b0b46989dd number of countries with olive tree plantations is increasing, production and exporting dominance will remain located in countries bordering the Mediterranean for a long time. Producer countries with the capacity to vie for global leadership in the export market are not expected to appear on the world stage, but nor is their role expected to diminish. The reason is that they have conditions that make them very competitive. It used to be affirmed that "the Mediterranean ends where the olive tree stops growing" (Georges Duhamel); nowadays, the olive tree reproduces far beyond the geographical boundaries of this region saddled between three continents.

The tension between consolidated and new producers is not, in any case, an issue that we should examine at the scale of the different countries that make up the olive world, but rather that of each particular farm. The contrasts are, accordingly, between small farms on rain-fed lands located in areas that enjoy far from ideal agronomic conditions (especially in the case of olive groves in the mountains) and large irrigated farms that occupy very fertile lands and are professionally managed. The former correspond to the template of family agriculture and try to maintain themselves through formulas of cooperation and by trying to incorporate elements of postproductivism (differentiation, organic farming, tourism activities, income supplementation with other activities) and, in the case of European countries, by taking advantage of CAP support. The latter follow an agrobusiness blueprint and have been designed to compete under strict market conditions under the principles of productivism, with significantly lower costs to obtain the oil (IOC, 215). New technological advances, such as the use of drones to monitor the crop or harvesting machines that are more efficient or completely robotic, will mean an even greater distance between each model. Access to the land/water duality and to financial capital will, in this latter model, be decisive for the location of the new plantations that follow these high-tech models. On the other hand, for traditional specialized territories, the losses that they may have in productive terms may well be offset, as is already happening in Andalusia, with the development of their potential in terms of research, innovation and commercialization. 


\section{ACKNOWLEDGMENTS}

This research is part of a wider research project entitled "Characterization and perspectives of the olive monoculture in Jaén: its spatial and chronological formation, landscape-agronomic diversity and immediate territorial dynamics", which is funded by the Ministry of Economy, Innovation and Science of the Regional Government of Andalusia (SEJ-1153, session 2012).

\section{REFERENCE}

[1]. Agence Pour le Développement Agricole. (2009). Plan Maroc Vert. Retrieved from http://www.ada.gov.ma/ Plan Maroc Vert/plan-maroc-vert.php

[2]. Barjol, J. L. (2014). L'économie mondiale d'huile d'olive. $O C L, 21(5), \mathrm{D} 502$.

[3]. El-Kholy, M. (2012, Ed.). Following Olive Footprints (Olea Europaea L.). Cultivation and Culture, Folklores and History, Tradition and Uses. Córdoba: International Olive Council.

[4]. Bernstein, H. (2015). Food regimes and food regime analysis: a selective survey. In Land grabbing, conflict and agrarian-environmental transformations: perspectives from East and Southeast Asia. An international academic conference 5-6 June, 2015. Chiang Mai University. Retreived from https://www.iss. nl/fileadmin/ASSETS/iss/Research and projects/Resear ch networks/LDPI/CMCP 1- Bernstein.pdf

[5]. Civantos López-Villalta, L. (2004). La olivicultura en el mundo y en España. In D. Barranco, R. FernándezEscobar \& L. Rallo (Eds.), El cultivo del olivo (pp. 1935). Madrid: Ediciones Mundi-Prensa.

[6]. Clare, P. (2014). El cultivo de la palma aceitera en Costa Rica en el contexto del TLC con los Estados Unidos de América. Espiga, 9, 95-124.

[7]. Delgado Cabeza, M. (2012): La economía andaluza durante las tres últimas décadas, 1981-2011. In C. Jiménez de Madariaga, \& J. Hurtado Sánchez, J. (Eds.): Andalucía. Identidades culturales y dinámicas sociales (pp. 87-122). Sevilla: Aconcagua Libros.

[8]. European Economic Community, EEC. (1966). Regulation no 136/66/EEC of the Council of 22 September 1966 on the establishment of a common organisation of the market on oils and fats. Retrieved from https://publications.europa.eu/en/publicationdetail/-/publication/f5ef0761-2d02-4ddd-b2eaf154581e4cb4/language-en

[9]. European Union, EU. (1998). Amending Regulation No 136/66/EEC on the establishment of a common organisation of the market in oils and fats. Retrieved from

[10]. http://eur-lex.europa.eu/legalcontent/EN/TXT/?uri=CELEX\%3A31998R1638

[11]. Guiot, J. \& Cramer, W. (2016). Climate change: the 2015 Paris Agreement thresholds and Mediterranean basis ecosystems. Science, 354, 465-468.

[12]. Guo, X., Yan, D., Fan, J., Wanze, Z. \& Li, M. H. (2010). Using GIS and Fuzzy Sets to Evaluate the Olive Tree's Ecological Suitability in Sichuan Province. Compunting in Science \& Engineering, 12 (1), 20-27.

[13]. International Olive Council. (2015). International olive oil production costs study. Retrived from
[14]. http://www.internationaloliveoil.org/documents/index/18 15-international-olive-oil-production-costs-study

[15]. Jiménez, B. (2013). Eficiencia energética del aceite rojo de palma. Letras Verdes. Revista Latinoamericana de Estudios Socioambientales, 14, 322-337. Retrieved from

[16]. https://dialnet.unirioja.es/servlet/articulo? codigo $=54440$ $\underline{21}$

[17]. McMichael, P. (2014). Historicizing food sovereignty. The Journal of Peasant Studies, 41 (6), 933-957.

[18]. Moreno-Pérez, Olga M. (2015). Reproducing productivism in Spanish agricultural systems. Research in Rural Sociology and Development, 19, 121-147.

[19]. Moore, J.W. (2003). The Modern World-System as environmental history? Ecology and the rise of capitalism. Theory and Society, 32, 307-377.

[20]. Organisation For Economic Co-Operation And Development, OECD. (2006). The New Rural Paradigm: Policies and Governance. Retrieved from

[21]. http://www3.unisi.it/cipas/ref/OECD_2006_Rural_Parad igm.pdf

[22]. Parras Rosa, M. (2013). Plan de refuerzo de la competitividad del conglomerado agroindustrial olivícola de Uruguay, 2010-2020. Retrieved from

[23]. https://www.mgap.gub.uy/sites/default/files/multimedia/ plan conglomerado olivicola 2012-2020.pdf

[24]. Paul Miller \& Associates. (2012). Developing the Olive Industry in the Southeastern USA. A Study for Georgia Olive Farms. Retrieved from

[25]. http://georgiaolivefarms.com/gof/wpcontent/themes/southpaw-gof/docs/Georiga-OliveFarms-Developing-The-Olive-Industry.pdf

[26]. Pérez-Carrera, A., Moscuzza, C.H., Fernández-Cirelli, A. (2008). Efectos socioeconómicos y ambientales de la expansión agropecuaria. Estudio de caso: Santiago del Estero, Argentina. Ecosistemas 17 (1), 5-15. Retrieved from

http://www.revistaecosistemas.net/index.php/ecosistema s/article/viewFile/108/105

[27]. Rallo Romero, L., et al. (2005, Ed.). Variedades del olivo en España. Madrid: Ediciones Mundi-Prensa

[28]. Rastoin, J.L. (2016): "Redéployer la diète mediterranéenne par des systèmes alimentaires territorialisés". Journal Resolis, 12, 72-82.

[29]. Rodríguez-Cohard, J. C. \& Parras, M. (2011). The Olive Growing Agri-Industial District of Jaén and the International Olive Oils Cluster. The Open Geography Journal, 4, 55-72.

[30]. Rodríguez Cohard, J. C.; Sánchez Martínez, J. D. \& Gallego Simón, V. J. (2017). The Upgrading Strategy of Olive Oil Producers in Southern Spain: Origin, Development and Constraints. Rural Society, 26 (1). doi: 10.1080/10371656.2017.1285470.

[31]. Russo, C., Cappelletti, G. M., Nicoletti, G, M., Di Noia, A. E. \& Michalopoulus, G. (2016). Comparison of European Olive Production Systems. Sustainability, 8 (8), 825. doi:10.3390/su8080825

[32]. Sánchez Martínez, J. D. \& Paniza Cabrera, A. (2015). The Olive Monoculture in the South of Spain. European Journal of Geography, 6 (3), 16-29.

[33]. Sánchez Martínez, J. D. \& Gallego Simón, V. J. (2012). Olivares de alta densidad alentejanos y olivares tradicionales andaluces: un análisis comparado. In D. Royé, J. A. Aldrey, M. Valcárcel, M. Pazos \& M. J. Piñeira (Eds.): XIII Coloquio Ibérico de Geografia. Respuestas de la Geografia Ibérica a la crisis actual (pp. 1509-1518). Santiago de Compostela: Meubook.

[34]. Sánchez Martínez, J. D. (2016). La expansión geográfica de la olivicultura en la globalización. In J. Olcina Cantos 
\& A. M. Rico Amorós (Eds.): Libro jubilar en homenaje al profesor Antonio Gil Olcina (pp. 553-570). Alicante: Publicaciones de la Universidad de Alicante.

[35]. Scheidel, A. \& Krausmann, F. (2011): Diet, trade and land use: a socio-ecological analysis of the transformation of the olive oil system. Land Use Policy, $28,47-56$.

[36]. Stinchcombe, A. L. (1996). Sugar Island Slavery in the Age of Enlightenment: The Political Economy of the Caribbean World. Princeton, NJ: Princeton University Pres.

[37]. United State Department of Agriculture, USDA. (2013, August). Olive Oil: Conditions of Competition between U.S. and Major Foreign Supplier Industries. Retrieved from

[38]. https://www.usitc.gov/publications/332/pub4419.pdf

[39]. United States Departament of Agriculture, USDA. (2015, March). Oils Crops Yearbook, 2015. Retrieved from

[40]. http://usda.mannlib.cornell.edu/MannUsda/viewStaticPa ge.do?url=http://usda.mannlib.cornell.edu/usda/ers/ 8900 2/2015/index.html

[41]. Vilar Hernández, J. \& Cárdenas García, J. R. (2016). El sector internacional de elaboración de aceite de oliva: un estudio descriptivo de los 56 países productores. Andújar: GEA - Centro Internacional de Excelencia para el aceite de oliva.

[42]. Wilson, G.A. (2001). From productivism to postproductivism... and back again? Exploring the (un)changed natural and mental landscapes of European agriculture. Transactions of the Institute of British Geographers, 26 (1), 77-102.

José D. Sánchez-Martínez; Departamento de Antropología, Geografía e Historia, Universidad de Jaén, Campus de Las Lagunillas s/n, 23071 Spain; jdsanche@ujaen.es +34 953212957

Antonio Garrido-Almonacid, Departamento de Ingenería Cartográfica, Universidad de Jaén. Campus de Las Lagunillas s/n, 23071 - Spain; agarrido@ujaen.es; +34 953212459 


\title{
Canh tác Olive trong kỷ nguyên toàn cầu hóa
}

\author{
J.D. Sánchez-Martínez, A. Garrido-Almonacid \\ Đại học de Jaén, Tây Ban Nha \\ Email tác giả liên hệ: jdsanche@ujaen.es
}

Ngày nhận bản thảo: 11/12/2017; ngày chấp nhận đăng: 27/01/2018; ngày đăng: 30/3/2018

Tóm tắt-Việc tiêu thụ ô liu và dầu ô liu đã có mặt từ rất lâu đời ở Địa Trung Hải. Có hương vị tuyệt vời, tốt cho sức khỏe con người, lại khá hiếm quý, những sản phẩm từ cây olive ở vùng này rất được tin dùng và có giá khá cao khi được bán ra, dù thị trường cây ô liu toàn cầu không ngừng phát triển trong suốt nhiều thập kỷ qua. Trong bối cảnh này, ta có thể nhận thấy một sự tăng trưởng về mặt sản lượng của các sản phẩm này tại vùng đất khởi nguồn của cây ô liu. Song loài cây này cũng đang được trồng tại các khu vực mà điều kiện thời tiết không cần thiết quá lý tưởng cho sự sinh trưởng của nó.
Mục đích của bài nghiên cứu này là trình bày tình hình phát triển năng động của cây ô liu theo quan điểm không gian và thời gian. Tù̀ đó, chúng tôi kết luận rằng, chu trình này có tiềm năng phát triển rất quan trọng ở tương lai, nhưng không loại trừ những giới hạn và hoài nghi cả về các vùng sản xuất mới lẫn vùng Địa Trung Hải vốn đã có hàng ngàn năm canh tác ô liu.

Tù khóa- dầu ô liu, olive để ăn, kinh tế nông nghiệp, độc canh, toàn cầu hóa kinh tế 